MENYAMA BRAYADALAM KEHIDUPAN MASYARAKAT ISLAM DAN HINDU DI DESA PEGAYAMANAN KECAMATAN SUKASADA KABUPATEN BULELENG TAHUN 2013

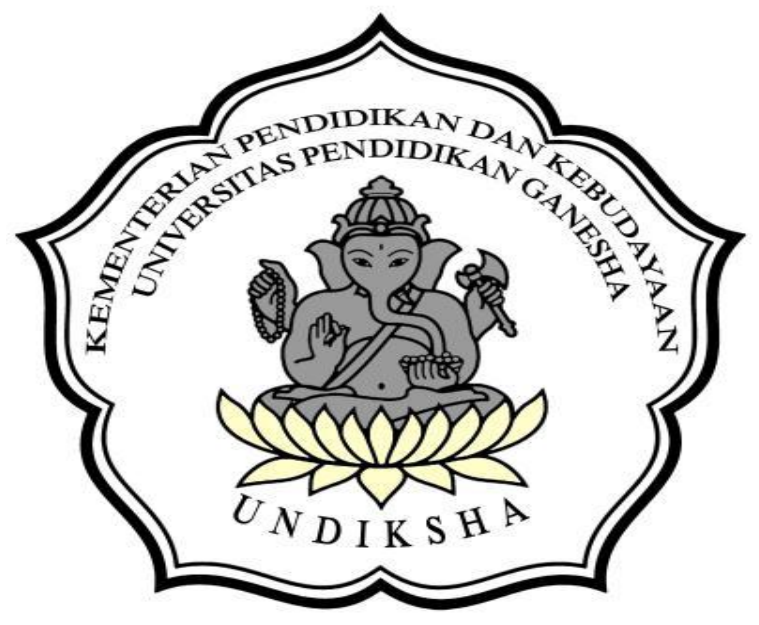

ARTIKEL

OLEH :

I PUTU SOVIAWAN

1014041001

JURUSAN PENDIDIKAN PANCASILA DAN KEWARGANEGARAAN

FAKULTAS ILMU SOSIAL

UNIVERSITAS PENDIDIKAN GANESHA 


\title{
MENYAMA BRAYADALAM KEHIDUPAN MASYARAKAT ISLAM DAN HINDU DI DESA PEGAYAMANAN KECAMATAN SUKASADA KABUPATEN BULELENG TAHUN 2013
}

\author{
Oleh \\ I Putu Soviawan \\ Drs. I Wayan Landrawan,M.Si \\ Ratna Artha Windari,SH.,MH \\ Jurusan Pendidikan Pancasila dan Kewarganegaraan \\ Fakultas Ilmu Sosial \\ Universitas Pendidikan Ganesha
}

\begin{abstract}
ABSTRAK
Penelitian ini bertujuan sebagai berikut : (1) mengetahui dinamika hubungan sosial di Desa Pegayaman, Kecamatan Suksasada, Kabupaten Buleleng (2) memahami pandangan masyarakat Hindu dan Islam di Desa Pegayaman, Kecamatan Suksasada Kabupaten, Buleleng terhadap nilai menyama braya, (3) Untuk mengidentifikasi bentuk hubungan menyama braya dalam kehidupan sosial di Desa Pegayaman, Kecamatan Sukasada, Kabupaten Buleleng.

Penelitian ini menggunakan pendekatan penelitian deskriptif kualitatif. Subyek penelitian adalah Kepala Desa Pegayaman, Bendesa Adat Desa Pegayaman, Ketua Majelis Madya Singaraja, Masyarakat Desa Pegayaman yang mewakili masyarakat Islam dan Hindu. Teknik pengumpulan data yang digunakan adalah metode observasi, wawancara dan dokumentasi.

Hasil penelitian ini menunjukkan bahwa : (1). Dinamika hubungan sosial pada saat ini masih tetap terjalin dengan baik yang disebabkan oleh faktor sejarah, faktor ideologi dan tradisi kebersamaan. Dan konsep menyama braya ini sudah ada sejak zaman dahulu, karena konsep ini mampu mempererat hubungan baik yang memiliki agama yang berbeda atau ras yang berbeda. (2). Pandangan masyarakat Islam tercermin dari konsep Ukhuwah Islamiyah dan Rahmatan Lil Alamin terhadap konsep menyama braya yakni dalam bentuk hubungan baik sesama manusia. Sedangkan pandangan masyarakat Hindu mengenai menyama braya terwujud dalam bentuk Tat Tvam Asi, Tri Hita Karana, Catur Paramitha dan Catur Parweti selanjutnya dimaknai sebagai toleransi atau kebersamaan masyarakat yang multi budaya, multi etnis dan multi agama. (3). Bentuk-bentuk hubungan harmonis antara masyarakat Hindu dan Islam dapat dilihat pada setiap lini kehidupan baik dibidang sosial maupun budaya yakni (1). Ngejot, 2) Kesenian Bordah dan 3). Gotong royong, 4). Sokok Base dan 5) Sistem Pengaturan Desa
\end{abstract}

Kata Kunci : Menyama braya, Hindu, Islam dan Desa Pegayaman. 


\title{
MENYAME BRAYE IN MUSLIMS AND HINDUS IN PEGAYAMAN VILLAGE SUB DISTRICT SUKASADA BULELELNG REGENCY 2013
}

\author{
By : \\ I Putu Soviawan \\ Drs. I Wayan Landrawan,M.Si \\ Ratna Artha Windari,SH.,MH \\ Pancasila and Civics Education Department \\ Faculty of Social Knowledge \\ Ganesha University of Education
}

\begin{abstract}
This research aims to: (1) Knowing the social relationship in Pegayaman village sub district Sukasada, Buleleng Regency. (2) Understanding the views of menyama braya value in Hindus and Muslims in Pegayaman village, sub district Sukasada, Bulelelng Regency, (3) Identifying the form of menyama braya relationship in social interaction at Pegayaman village, sub district Sukasada, Buleleng Regency.

The methodology of this research uses descriptive qualitative approach. The subjects of this research are the head of Pegayaman village, the head of religion village of Pegayaman, the head of middle council Singaraja, the Hindus and Muslims in Pegayaman village.

The result of this research shows that: (1) the development of social relation is still has good relationship because of history, ideology and the togetherness's tradition of villagers. The concept of menyama braya was built from previous era, because this concept cab built good relationship between two different religions or two different ethics. (2) the views of Muslims in menyama braya is the harmony of human relationship as social community which is related to Ukhuwah Islamiyah and Rahmatan Lil Alamin, on the other hand the hindus's views about menyama braya is understood as the togetherness of people in multi cultures, multi ethnics and multi religions, in which it can be obtained in the form of Tatwam Asi, Tri Hita Karana, Catur Paramitha and Catur Parweti. (3) The form of harmony relationship between Hindus and Muslims can be seen from every single life, such as in social life and culture, for instance, 1) Ngejot , 2) Bordah art, 3). Helping each other, 4). Sokok Base and 5). System of setting village.
\end{abstract}

Key words: menyame braye, hinduse, muslims and Pegayaman village. 


\section{PENDAHULUAN}

Keanekaragaman merupakan potensi yang besar dalam memperkaya kebudayaan nasional Bangsa Indonesia seperti yang telah diamanahkan dalam Undang-Undang Dasar 1945 Pasal 32.“ Hubungan sosial yang dinamis atau interaksi sosial antar suku bangsa yang berbeda menjadi amat penting dalam proses integrasi nasional bangsa Indonesia”. ( Suhardi, 1995 : 1 ). Keanekaragaman bangsa Bangsa Indonesia juga dapat menyebabkan munculnya disintegrasi bangsa, seperti yang disebutkan oleh Salim ( 1999 : 50). Pada kenyataannya keanekaragaman agama, sosial budaya, suku, kebiasaan, adat istiadat dan sebagainya secara sosiologis rentan menimbulkan konflik,, namun tidak demikian halnya yang terjadi di Bali. Walaupun masyarakat bersikap multietnik seperti perbedaan agama, suku dan sosial budaya, namun kenyataannya orang-orang yang berasal dari luar Bali mampu menjalin hubungan yang rukun dan menciptakan keharmonisan dengan penduduk asli Bali yang didominasi dengan agama Hindu.

Manusia Bali yang ada di pulau Bali terdiri dari berbagai macam agama, yakni dominasi agama Hindu, lalu ada umat yang beragama Islam, Budha, Khatolik bahkan Kristen.Namun kenyataannya tidak semua orang Bali beragama Hindu, sudah sangat banyak agama-agama lain yang berkembang di Bali seperti yang disebutkan sebelumnya sehingga hal ini menunjukkan bahwa masyarakat Bali adalah masyarakat yang pluralitas baik dari segi etnis, agama, sosial budaya dan sebagainya.

Pluralitas agama yang dimaksud adalah terdapat lebih dari satu agama yang mempunyai eksistensi hidup berdampingan, saling bekerja sama dan saling berinteraksi antara penganut agama satu dengan penganut agama lainnya. ( Rumidan, 25 : 2010 ). Pluralitas agama bukanlah semata-mata realitas sosial, namun juga adalahfenomena teologis, karena itu pada satu sisi pluralitas agama adalah sebuahkekayaan yang indah dan dinamik,Pada sisi yang lain,sekaligus juga adalah tantangan sebab didalamnya mengandung potensi konflik tidakhanya berupa konflik antar umat beragama, tetapi juga perpecahan atau sangat rentanterhadap konflik sosial dan disintegrasi bangsa. 
Pluralitas agama tidak hanya memainkanperanan yang integratif dan menciptakan harmoni sosial saja dalam masyarakat, tapi jugaperanan pemecah yang menumbulkan disintegrasi (Geertz 1981: 475).Tidak jarang hubungan antar etnik, budaya danagama di Indonesia dilatarbelakangi suasana persaingan.Persaingan-persainganmemunculkan potensi konflik (Koentjaraningrat 1990: 143).Dan karena terdapat diferensiasi dalam bidang agama maka memungkinkan untuk timbulnya sebuah konflik-konflik baik dalam lingkup besar maupun kecil.Salah satu usaha untuk mencari keharmonisan suatu etnik dalam masyarakat adalah dengan jalan memelihara dan membina hubungan yang baik dengan masyarakat yang berbeda etnis yang masing-masing dari etnis tersebut memiliki kesenian yang berbeda-beda sehingga seni budaya yang ada pada setiap daerah dapat dikembangkan dengan baik, maka haruslah membenahi seni budaya yang dimiliki.

Sistem nilai sosial yang terkenal digunakan pada masyarakat Bali Hindu adalah menyama braya yang berarti suatu ikatan persaudaran yang menganggap orang lain itu adalah saudara. Dengan konsep ini diharapkan mampu menjaga keharmonisan umat beragama tidak hanya di Bali, tetapi juga wilayah-wilayah lain yang memiliki pluralitas agama dapat mengadopsi nilai ini. Karena dengan konsep ini kemungkinan timbulnya konflik sangat kecil sebab konsep ini lebih menekankan terhadap perlakuan terhadap orang lain, apabila kita menyakiti orang lain atau saudara kita sendiri, maka sama dengan menyakiti diri sendiri. Salah satu daerah yang identik dengan meyama braya yang merupakan hubungan harmonis antara umat Hindu dan Islam yakni Desa Pegayamanan yang terletak di Kebupaten Buleleng.

Berdasarkan latar belakang seperti apa yang diuraikan diatas maka terdapat beberapa permasalahan yang layak dikedepankan, yaitu: 1). anakah dinamika hubungan sosial masyarakat Hindu dan Islam Desa Pegayaman, Kecamatan Suksasada Kabupaten Buleleng. 2). Bagaimana pandangan masyarakat Hindu dan Islam di Desa Pegayaman, Kecamatan Suksasada Kabupaten Buleleng terhadap nilai menyama braya.3). Bagaimanakah bentuk hubungan menyama brayadalam kehidupan sosial di Desa Pegayaman, Kecamatan Suksasada Kabupaten Buleleng. 


\section{METODE PENELITIAN}

Penelitian ini menggunakan pendekatan empiris, yaitu suatu cara pendekatan di mana gejala yang akan diselidiki telah ada secara wajar (real situation) (Mardalis, 1994:35).subjek penelitian yaitu : (1) Kepala Desa Pegayaman; (2) Masyarakat Hindu di Desa Pegayaman; (3) Masyarakat Islam di Desa Pegayaman; (4) Bendesa Adat Desa Pegayaman; (5) Ketua Majelis Madya Singaraja. Penentuan subjek dalam penelitian ini menggunakan teknik Purposive yaitu penelitian berdasarkan pertimbangan tujuan penelitian, bahwa informan tersebut dapat memberikan informasi yang dibutuhkan untuk penelitian.(Sugiyono, 2010:218).Sesuai dengan jenis data yang diperlukan dalam penelitian ini, maka pengumpulan data dalam penelitian menganut prinsip Human Instrument, yaitu peneliti merupakan instrument penelitian yang utama seperti yang dinyatakan oleh Carspecken (1998) dalam laporan penelitian Pursika (2008:28). Namun, dalam pelaksanaannya peneliti juga akan menggunakan beberapa instrument dan teknik pengumpul data, yaitu : metode wawancara, metode observasi dan metode dokumentasi.

Teknik analisis data yang digunakan dalam penelitian ini adalah analisis data deskriptif kulitatif.Deskriptif kualitatif yaitu penelitian yang dilakukan untuk menggambarkan suatu variabel secara mandiri, baik satu variabel atau lebih tanpa membuat perbandingan atau menghubungkan variabel dengan variabel lainnya (Narbuko dan Achmadi, 2005:44).

\section{HASIL PENELITIAN DAN PEMBAHASAN}

\subsection{Dinamika Hubungan Sosial Masyarakat Hindu dan Islam Desa Pegayaman, Kecamatan Suksasada Kabupaten Buleleng}

Berbicara mengenai menyama braya di Desa Pegayaman paling tidak ada tiga alasan yang menjadi dasar tetap dilaksanakannya menyama braya di Desa Pegayaman yang diungkapkan oleh Abdul Manaf adalah :

"Menyama braya tetap ada dan terlaksana hingga saat ini dikarenakan oleh beberapa alasan yaitu faktor sejarah, faktor ideologi dan tradisi kebersamaan. Perlu digaris bawahi bahwa menyama braya walaupun sudah terjalin dan ada sejak zaman dahulu tetapi hingga saat ini masih tetap ada" ( Wawancara tanggal 28 Oktober 2013) 
Berdasarkan wawancara tersebut, maka dapat dipaparkan alasan mengapa menyama braya tetap ada di Desa Pegayaman yakni sebagai berikut :

\section{Faktor Sejarah}

Bahwasanya pelaksanaan menyama braya di Desa Pegayaman tidak terlepas dari sejarah kedatangan masyarakat Islam di Kabupaten Buleleng, karena kebaikan masyarakat Islam itu sehingga Raja Buleleng menghadiahi lahan tanah yang terletak dibagian selatan Kabupaten Buleleng. Kebaikan ini tidak terlepas masyarakat Islam menjalin hubungan harmonis dengan masyarakat Hindu yang ada di Buleleng hal ini terlihat pada saat pemberontakan atau penyerangan Kerajaan Mengwi ke Buleleng yang mana masyarakat Hindu dalam hal ini Pasukan Goak yang ada desa Panji bekerjasama dengan masyarakat Islam pasukan Pegayaman yang terletak di desa Pegayaman untuk menyerang pasukan kerajaan Mengwi yang pada akhirnya mereka mampu menyerang hingga pasukan kerajaan Mengwi mundur.

2. Faktor Ideologi

Bangsa Indonesia adalah bangsa yang didasarkan pada ideologi yang sangat kuat yakni Pancasila yang salah satu turunan nilainya adalah Bhineka Tunggal Ika yang berarti berbeda-beda tetapi satu jua. Landasan inilah yang menjadi dasar pelaksanaan menyama braya di Desa Pegayaman yang mana masyarakat setempat menyadari bahwa setiap perbedaan yang ada tetap dihormati seperti perbedaan agama yang menyatakan agamamu agamaku yang berarti adanya sikap menghargai agama orang lain baik itu tidak mengganggu agama lain untuk beribadah dan lain sebagainya.

3. Tradisi Kebersamaan

Salah satu tradisi yang memunculkan kebersamaan adalah tradisi ngejot, tradisi ini biasa dilakukan oleh umat Hindu dan Islam pada hari raya besar keagamaan seperti Galungan dan Kuningan, Idul Fitri.Ngejot ini memiliki beberapa fungsi yakni ngejot sebagai bentuk permakluman kepada yang diberi jotan bahwa yang ngejot tersebut memiliki acara tertentu, fungsi selanjutnya sebagai undangan untuk datang ketempat orang yang ngejot 
tersebut.Fungsi yang lainnya adalah untuk ucapan terimaksih karena yang diberi jotan tersebut telah membantu dalam penyelesaian sebuah upacara tertentu yang dilakukan orang yang memberi jotan tersebut.

\subsection{Pandangan Masyarakat Hindu dan Islam di Desa Pegayaman,} Kecamatan Suksasada Kabupaten Buleleng Terhadap Nilai Menyama

\section{Braya}

Tokoh agama Islam Amir Amzah mengatakan bahwa :

"Menyama braya adalah toleransi atau kebersamaan masyarakat yang multi budaya, multi etnis dan multi agama. Seperti contoh adalah pembangunan masjid Jamik Safinatusalam memang tidak terlepas dari gontong royong dan kerja sama masyarakat Hindu yang ada di Desa Pegayaman.” ( Wawancara tanggal 28 Nopember 2013 )

Dan menurut masyarakat Islam nilai-nilai sosial yang terdapat dalam menyama braya memiliki kesamaan atau terdapat dalam konsep Ukhuwah Islamiyahdan Rahmatan Lil AlaminYang dimana menurut Abdul Manaf selaku tokoh Islam di Desa Pegayaman menyatakan arti kedua kedua tersebut yakni sebagai berikut :

"Ukhuwah Islamiyah adalah sistem bagaimana manusia mampu bermasyarakat sesuai dengan rukun islam yakni hubungan yang harmonis dengan Tuhan, Manusia dan Tumbuhan yang ditambah dengan percaya dengan kiamat.Sedangkan Rahmatan Lil Alamin adalah rahmat kepada seluruh umat manusia. Karena seluruh umat manusia memiliki nilai plus"( Wawancara tanggal 28 Oktober 2013 )

Berdasarkan pengertian yang dipaaparkan, maka Ukhuwah Islamiyahdan Rahmatan Lil Alaminhampir sama dengan menyama braya yang dimana intinya adalah kehidupan bermasyarakat dan kerukunan antar umat beragama.

Menyama braya menurut pandangan Hindu, penulis melaksanakan wawancara pada masyarakat Hindu yang berada di dusun Amertasari yang dimana banjar ini penduduk Hindunya lebih banyak dibandingkan banjar-banjar yang lainnya. Made Gunarsa mengatakan bahwa :

"Menyama braya menurut saya adalah hubungan yang baik dengan kita sesama manusia, tidak hanya sesama masyarakat Hindu tetapi juga pada masyarakat Islam. Sehingga dengan menjalin hubungan yang harmonis saya yakin kita akan selalu damai" ( Wawancara tanggal 28 Nopember 2013 ). 
Menyama Braya selanjutnya dimaknai sebagai toleransi atau kebersamaan masyarakat yang multi budaya, multi etnis dan multi agama yang dalam hal ini dapat terwujud dalam bentuk Tat Tvam Asi dan Tri Hita Karana.

Menurut Bendesa Adat Desa Pegayaman mengatakan bahwa :

" Tat Tvam Asi adalah suatu paham yang menyatakan bahwa aku adalah kamu, sehingga apa yang dirasakan oleh aku maka kamu akan merasakannya juga. Sedangkan Tri Hita Karana adalah suatu bentuk hubungan manusia dengan Tuhan, manusia dengan sesama manusia serta manusia dengan lingkungannya sehingga timbul suatu kerukunan dan keseimbangan hidup" ( Wawancara tanggal 20 Nopember 2013 )

Berdasarkan hal tersebut, bila kita mengacu pada pengertian menyama braya yakni menyama braya adalah suatu cara hidup yang memahami bahwa semua manusia adalah bersaudara atau cara hidup yang memperlakukan orang lain seperti saudara sendiri. Nilai tersebut hampi sama dengan konsep Tat Tvam Asi dan Tri Hita Karana yang telah diungkapkan oleh Bendesa Adat.

\subsection{Bentuk Hubungan Menyama Braya Dalam Kehidupan Sosial di Desa Pegayaman, Kecamatan Suksasada Kabupaten Buleleng}

Bentuk hubungan sosial antara masyarakat Hindu dan Islam dapat dijelaskan sebagai berikut :

1. Ngejot

Ngejot sebagai salah satu upaya untuk menjalin hubungan harmonis antar umat beragama. Ngejot ini diartikan sebagai bentuk hubungan harmonis masyarakat Hindu dan Islam, sebagai salah satu contoh hari raya Idul Adha masyarakat Islam membagikan sebagian makanan itu kepada tetangga didekat rumah termasuk juga masyarakat umat Hindu. Begitu juga sebaliknya apabila masyarakat umat Hindu memiliki acara agama seperti Galungan membagikan sebagian buah-buahan kepada masyarakat Islam. 


\section{Borda}

Dibidang budaya, bentuk hubungan harmonis salah satunya adalah kesenian Borda.Borda merupakan kesenian musik masyarakat Islam dalam bidang tabuh yang memiliki kemiripan dengan tabuh-tabuh masyarakat Hindu pada umumnya.Hubungan dengan Hindu terletak pada alat music yang digunakan yakni tabuh juga terletak pada pakaian yang digunakan yakni menggunakan udeng yang merupakan ciri khas masyarakat Hindu.Seliain itu kesenian ini memiliki kesamaan pada nada dan irama seperti mekidung di pura.Borda biasanya dilaksanakan pada hari raya Maulid Nabi, Sunatan warga.

3. Gontong royong

Bentuk interaksi lainnya adalah adanya kesadaran untuk ikut menaga kelestarian lingkungan dalam hal ini adalah Palemahan dalam ajaran Tri Hita Karana dalam bentuk gotong royong yakni masyarakat Hindu dan Islam secara bersama-sama ikut melaksanakan pembersihan desa baik itu diareal Kantor Kepala Desa maupun lingkungan sekitar, kegiatan ini biasanya dilakukan saat menyambut hari-hari Nasional seperti 17 Agustus, Galungan dan Kuningan, Idul Fitri dan lain sebagainya. Sebagai salah satu bukti yakni kegiatan Maulid Nabi pihak dari panitia mengundang tokoh-tokoh dan masyarakat Hindu untuk melaksanakan gotong royong bersama.

Hubungan harmonis lainnya terletak pada toleransi dan menghargai kewajiban umat Bergama, salah satu contoh adalah apabila masyarakat Hindu memiliki upacara agama dan biasanya mengundang tokoh-tokoh Islam untuk hadir, bentuk toleransinya adalah bagi tokohtokoh Islam disediakan tempat khusus dan untuk makanan pihak yang mengundang terlebih dahulu mengundang umat Islam untuk menyediakan makanan sehingga makanan yang dimakan tersebut tetap halal. Lalu mengenai alat komunikasi yang digunakan adalah bahasa Bali yang merupakan bahasa masyarakat Bali yang didominasi oleh masyarakat Hindu. 


\section{Sokok Base}

Kebudayaan merupakan salah satu akulturasi budaya antara masyarakat Hindu dan Islam. Apabila masyarakat Hindu mempunyai pajegan yaitu sarana upacara berupa buah-buahan yang ditusukkan pada batang pohon pisang, buah-buahan yang dimaksud adalah buahan-buahan yang sesuai dengan adat dan tradisi yang ada seperti buah pisang, apel, salak, jeruk, mangga dan lain sebagainya. Tetapi berbeda dengan masyarakat Islam yang ada didesa Pegayaman yakni adanya Sokok Base yaitu sarana upacara yang memiliki kemiripan dengan pajegan, tetapi Sokok Base bahan utamanya bukanlah buah tetapi base (dalam bahasa Indonesia daun sirih) yang bentuknya hampir menyerupai pajegan yakni menjulang keatas. Sokok Base dilaksanakan setiap tanggal 14 Januari, Sokok Base ini merupakan bentuk wujud syukur masyarakat Desa Pegayaman karena tanaman tumbuh dengan baik dan subur. Makna filosofis yang terdapat dalam Sokok Base adalah berbagai macam adat istiadat yang diibaratkan dengan tanaman, mampu hidup berdampingan dan menjadi satu antara masyarakat Hindu dan Islam di Desa Pegayaman.

\section{Sistem Pengaturan Desa}

Desa Pegayaman yang didominasi oleh masyarakat Islam tetapi tetap menggunakan beberapa istilah masyarakat Bali misalnya dalam sistem pengaturan desa seperti yang dipaparkan pada gambaran umum Desa Pegayaman yang disebutkan bahwa desa Pegayaman terdiri dari lima banjar yakni 1). Banjar Dinas Barat Jalan, 2). Banjar Dinas Timur Jalan, 3). Banjar Dinas Kubu, 4). Banjar Dinas Amertasari, 5). Banjar Dinas 
Kubu Lebah. Berdasarkan pada pembagian tersebut yang menggunakan istilah Bali yakni kata banjar, bila kita kaji lebih dalam lagi banjar merupakan kesatuan masyarakat hukum yang memiliki batas-batas wilayah yang berwenang untuk mengatur dan mengurus kepentingan masyarakat setempat.

\section{PENUTUP}

Sesuai dengan pembahasan pokok permasalahan di atas, maka dapat ditarik simpulan bahwaapabila berbicara mengenai dinamika hubungan sosial maka kita berbicara tentang perkembangan hubungan sosial itu sendiri. Kerukunan umat beragama sebenarnya sudah terjaga sejak beberapa tahun yang lalu melalui menyama braya dengan beberapa bukti yang ada diantaranya adalah kerukunan kehidupan bermasayarakat didesa Pegayaman yang hingga saat ini tidak pernah terjadi konflik yang bernuansa agama. Berbicara mengenai menyama braya di Desa Pegayaman paling tidak ada tiga alasan yang menjadi dasar pelaksanaannya menyama braya sehingga masih terlaksana hingga saat ini yakni faktor sejarah, faktor ideologi dan tradisi kebersamaan. Menyama braya menurut agama Islam diartikan sebagai sebuah interaksi sosial yang menghargai perbedaan baik dari suku, agama dan bahasa.Yang dimana ajaran menyama braya ini hampir sama dengan konsep Ukhwwah Islamiyahdan Rahmatan Lil Alamin.Lalu menyama braya menurut umat Hindu di Desa Pegayaman adalah suatu cara hidup yang memahami bahwa semua manusia adalah bersaudara atau cara hidup yang memperlakukan orang lain seperti saudara sendiri, selanjutnya dimaknai sebagai toleransi atau kebersamaan masyarakat yang multi budaya, multi etnis dan multi agama yang dalam hal ini dapat terwujud dalam bentuk Tat Tvam Asi dan Tri Hita Karana.

Berdasarkan hasil penelitian yang dilakukan bahwa desa Pegayaman lebih condong pada bentuk integrasi normatif, dimana integrasi normatif ini berdasarkan pada kesepakatan dan kepatuhan yang membudaya terhadap nilainilai dan norma-norma tertentu yang merupakan integrasi yang terjadi akibat adanya norma-norma yang berlaku dimasyarakat. Salah satu bukti yang 
menunjukkan hal ini adalah adanya akulturasi budaya antara masyarakat Hindu dan Islam seperti misalnya ngejot, kesenian Bordah, gotong royong, sokok base dan sistem pengaturan desa.

\section{DAFTAR PUSTAKA}

Koentjaraningrat. 1987. Pendahuluan dalam Manusia dan Kebudayaan di Indonesia. Djembatan : Jakarta

Mardalis. 1994. Metode Peneltian Suatu Pendekatan Proposal. Surabaya: Usaha Nasional.

Narbuko, Choliddan H. Abu Achmadi. 2005. MetodologiPenelitian. Jakarta: PTBumiAksara.

Rumidan, dkk.2010. Wacana Perdamaian dan Toleransi Agama- Agama di Indonesia. Jakarta. Kementerian Pendidikan Nasional

Salim, Emil. 1999. Membangun Integrasi Bangsa dalam Sejarah Pemikiran Rekontruksi.Persepsi.MSI. Jakarta

Suhardi, Ahmad, dkk. 1995. Corak dan Pola Kehidupan Sosial Budaya di Daerah Perbatasan Studi Tentang Pelestarian Batas-Batas Etnis di Gilimanuk.Jakarta : CV. Eka Putra

Sugiyono.2010. MetodePenelitianKuantitatifKualitatifdan $R \& D$. Bandung: Alfabeta 